\title{
Chemoresistance and cancer-related inflammation: two hallmarks of cancer connected by an atypical link, PKC $\zeta$
}

\section{Alessandro Rimessi, Simone Patergnani, Elli loannidi and Paolo Pinton*}

Section of Pathology, Oncology and Experimental Biology, Laboratory for Technologies of Advanced Therapies (LTTA), Department of Morphology, Surgery and Experimental Medicine, Interdisciplinary Center for the Study of Inflammation (ICSI), University of Ferrara, Ferrara, Italy

\section{Edited by:}

Hans-Uwe Simon, University of Bern Switzerland

Reviewed by:

Deborah Stroka, University of Bern, Switzerland

Frank Kruyt, University Medical

Center Groningen, Netherlands

\section{*Correspondence:}

Paolo Pinton, Section of Pathology,

Oncology and Experimental Biology,

Laboratory for Technologies of

Advanced Therapies (LTTA),

Department of Morphology, Surgery

and Experimental Medicine,

Interdisciplinary Center for the Study

of Inflammation (ICSI), University of

Ferrara, Via Borsari 46, 44121 Ferrara,

Italy

e-mail:pnp@unife.it
Atypical protein kinase $\mathrm{C}$ isoforms are serine threonine kinases involved in various pathological conditions. In recent years, the PKC $\zeta$ isoform has emerged as an important regulator of multiple cellular processes operating in cancer. In this review, we will focus on the $\mathrm{PKC} \zeta$ isoform as an oxidative-sensing kinase involved in cancer-related inflammation and chemoresistance. We will discuss its nuclear localization and its possible pivotal role in connecting inflammation with drug resistance.

Keywords: atypical PKC, $\mathrm{PKC}_{\zeta}$, cancer, chemoresistance, inflammation, nucleus, apoptosis

\section{INTRODUCTION}

The protein kinase C (PKC) family consists of serine/threonine kinases that can be grouped into three subfamilies based on their structure and activators (1-3). The proteins within the subfamilies differ in their primary structure, expression patterns, subcellular localization, in vitro activation, and responsiveness to extra-cellular signals, which suggests the existence of a complex molecular machinery that regulates the specific sorting of various isoforms.

Conventional PKCs are calcium dependent and are stimulated by the second messenger diacylglycerol. Novel PKCs are calcium independent but are also capable of being stimulated by diacylglycerol. However, atypical PKCs require neither calcium nor diacylglycerol for optimal activity (4) but, rather, are dependent on lipid components, such as phosphatidylinositols (PIs) (5), phosphatidic acid (6), arachidonic acid, and ceramide (7).

Inactive PKC is mainly present in the cytosol, whereas activated $\mathrm{PKC}$ is associated with the plasma membrane, nucleus, and other subcellular compartments (8-11). This differential localization or intracellular redistribution offers an important level

Abbreviations: AOM, azoxymethane; GLP, histone methyltransferase; IкB $\alpha$, nuclear factor of kappa light polypeptide gene enhancer in B-cells inhibitor alpha; IKK, IKB kinase; IL-1, interleukin 1; IL-6, interleukin 6; LPS, lipopolysaccharide; MEFs, mouse embryonic fibroblasts; MEK5, mitogen-activated protein kinase 5; NES nuclear export signal; NF- $\mathrm{kB}$, nuclear factor kappa B; NLS, nuclear localization signal; PAR6, par6 cell polarity protein; PHGDH, 3-phosphoglycerate dehydrogenase; PI3K, phosphatidylinositol 3-kinase; PIs, phosphatidylinositols; PKC, protein kinase C; PS, pseudosubstrate; SETD6, SET domain containing 6; Stat3, signal transducer and activator of transcription 3; TNF $\alpha$, tumor necrosis factor $\alpha$. of regulation of the kinase, favoring interactions with specific activators or substrates.

Researchers have demonstrated a role of oxidative stress in the activation and regulation of PKC. Oxidative stress is involved in the pathogenesis of various degenerative diseases, including cancer and inflammation (12-15). All of the isoforms of PKC contain regions in both the $\mathrm{N}$-terminal regulatory domain and the C-terminal catalytic domain that are susceptible to redox modifications (2). The sensitivity of PKC regions to redox stress interferes with the physiological activity of PKCs, and thus, with their biological effects.

Aberrant regulation or altered expression of PKCs has been implicated in the development, progression, and maintenance of the neoplastic phenotype $(16,17)$. Thus, logical candidates for the mediation of the pathological transduction of redox stress in cancer and cancer-related events are the PKCs.

In recent years, the atypical PKCs, particularly the $\zeta$ isoform, have emerged as pivotal regulators of cellular processes operating in cancer. The aim of this review was to summarize the available knowledge on the PKC $\zeta$ isoform in cancer and chemoresistance, thereby strengthening the link between PKC $\zeta$-dependent inflammation and chemosensitization.

\section{THE MULTIDOMAIN STRUCTURE OF ATYPICAL PROTEIN KINASE C ISOFORMS}

The atypical PKCs, which form a subgroup within the PKC family, consist of isoforms $\iota, \lambda$, and $\zeta$. PKC $\iota$ and PKC $\lambda$ are orthologs showing $98 \%$ overall amino acid sequence identity; hereafter, these proteins will be referred to as $\mathrm{PKCl} / \lambda$. 
Closer examination of protein sequence alignments between the $\mathrm{PKC}$ isoforms reveals sequence homology among the different members of this group. $\mathrm{PKC} \zeta$ and $\mathrm{PKCl} / \lambda$ consist of four functional domains, including a PB1 domain in the N-terminus, a pseudo-substrate (PS) domain, a C1 domain containing a single Cys-rich zinc finger motif, and a kinase domain at the C-terminus (Figure 1A) (10). The classical PKCs differ in their homologous domains (C2), which appears to be related to the $\mathrm{Ca}^{2+}$ sensitivity of the kinases. Both novel and atypical PKCs lack the C2 homologous domain and, thus, do not require $\mathrm{Ca}^{2+}$ for activation. In contrast, only the atypical PKCs additionally lack one-half of the $\mathrm{C} 1$ homologous domain (resulting in insensitivity to DAG) (Figure 1A).

The PB1 domain of PKC $\zeta$ recognizes the OPCA motifs of PAR6, ZIP/p62, and MEK5 (18). The PS domain blocks the substratebinding cavity of the kinase domain as an autoinhibitory mechanism. The kinase domain of $\mathrm{PKC} \zeta$ and other members includes an ATP-binding region, an activation loop, a turn motif, and a hydrophobic motif. The ATP-binding region contains the Lys-281
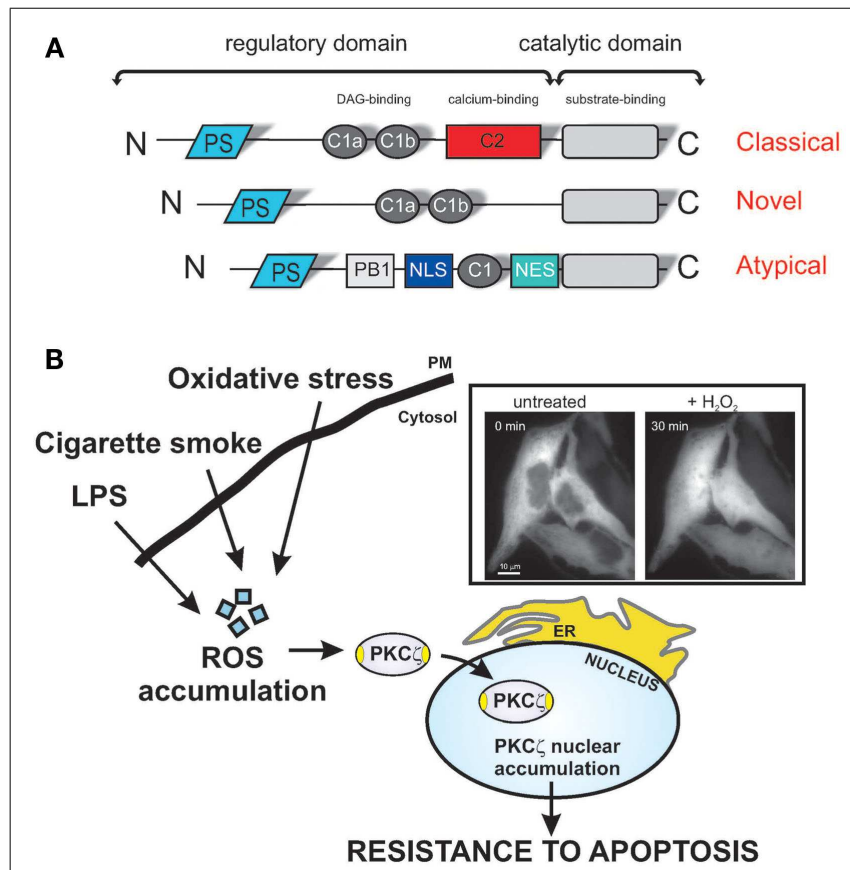

FIGURE 1 | Redox stress induces PKC $\zeta$ nuclear translocation, protecting cells via various apoptotic stimuli. (A) Schematic model of PKC structure. Representation of the different PKC subfamilies and their structural domains. The pseudo-substrate (PS) domain blocks the substrate-binding cavity of the kinase domain as an autoinhibitory mechanism. Conserved region $1(\mathrm{C} 1)$ confers binding to diacylglycerol (DAG) and phospholipids, and C2 senses calcium. The PB1 and NLS/NES domains are specific for atypical PKCs and act as a protein-binding domain and nuclear import-system domain, respectively. (B) Shows representative images of chimeric PKC $\zeta$ GFP-expressing HeLa cells in the resting condition (untreated) and after a 30-min treatment with $1 \mathrm{mM} \mathrm{H}_{2} \mathrm{O}_{2}$. PKC $\zeta$ localizes uniformly throughout the cytoplasm and is excluded from the nucleus, but upon oxidative stress challenge, the kinase translocates to the nucleus. Stress conditions, such the presence of as bacterial infection or cigarette smoke, favor the accumulation of intracellular ROS, and nuclear redistribution of the $\zeta$ isoform, conferring apoptotic resistance, and thus, chemoresistance. residue, which is crucial for its kinase activity, while the activation loop and turn motif contain threonine residues (Thr-410 and Thr560), which are phosphorylated upon activation. Finally, a nuclear localization signal (NLS) sequence is present in atypical PKCs that allows their rapid import into the nucleus via the formation of an NLS-importin complex (19), in addition to a short leucine-rich nuclear export signal (NES) sequence. NES-dependent nuclear export is inhibited by leptomycin $\mathrm{B}$, which interferes with the binding of NES to CRM1/exportin 1 (20). The exposure of the NLS in $\mathrm{PKC} \zeta$ may be regulated by intra-molecular interactions between the N-terminal region and the catalytic domain of the kinase. However, these conserved domains confer specific localization and/or activation inputs for the isotypes.

\section{ATYPICAL PROTEIN KINASE C ISOFORMS IN CANCER BIOLOGY}

In the last decade, atypical PKCs have been implicated in carcinogenesis. Several studies have reported that $\mathrm{PKCl} / \lambda$ plays a key role in the promotion of carcinogenesis, both in vitro and in vivo. For example, $\mathrm{PKCl} / \lambda$ is implicated in Ras signaling, and in particular, $\mathrm{PKCl} / \lambda$ is required for oncogenic Ras-mediated colon carcinogenesis (21). In this study, transgenic mice expressing a constitutively active form of $\mathrm{PKCl} / \lambda$ displayed a significant number of preneoplastic lesions in the colonic epithelium (21). $\mathrm{PKCl} / \lambda$ is also important in cancer development and chemotherapy resistance in non-small cell lung cancers and human colon carcinomas, in which the kinase is highly expressed. In fact, the introduction of a dominant negative $\mathrm{PKCl} / \lambda$ mutant or inhibition of its expression was found to block oncogenic transformation and increase sensitivity to chemotherapeutic agents (22). In summary, $\mathrm{PKCl} / \lambda$ can be considered an important oncogenic molecule whose expression can be used as a prognostic marker for several human cancers (23). As reported above, PKC $\zeta$ and $\mathrm{PKCl} / \lambda$ are members of the same group and exhibit $72 \%$ sequence homology at the amino acid level. However, $\mathrm{PKC} \zeta$ and $\mathrm{PKCl} / \lambda$ exhibit distinct functions, especially during cancer induction and maintenance, where $\mathrm{PKC} \zeta$ appears to play a controversial role in the neoplastic phenotype. $\mathrm{PKC} \zeta$ is not activated by diacylglycerol but is stimulated in vitro by the products of phosphatidylinositol 3-kinase (PI3-K), which strengthens its role in cellular proliferation. $\mathrm{PKC} \zeta$ interacts directly with Ras during mitogenic signaling. Ras has been demonstrated to interact in vitro with the regulatory domain of $\mathrm{PKC} \zeta$ and this association in vivo is triggered by platelet-derived growth factor (24).

A number of studies support the clinical relevance of $\mathrm{PKC} \zeta$ as a tumor suppressor, and a particular mutation in $\mathrm{PKC} \zeta$ has been found in human cancers (S514F) (25). The ability of PKCS overexpression to restrain Ras-induced tumorigenesis is severely inhibited by the PKC $\zeta 5514 F$ mutation (26) It has been difficult to establish whether PKC $\zeta$ is a pro- or anti-neoplastic protein, as a panel of human tumors was shown to exhibit contrasting protein expression levels of $\mathrm{PKC} \zeta(26,27)$. Furthermore, an anti-apoptotic effect and, recently, a chemoresistant effect have been attributed to $\operatorname{PKC\zeta }(8)$.

In the following sections, we will attempt to elucidate the involvement of the $\zeta$ isoform in carcinogenesis and its putative role as a chemosensitizer. 


\section{PKC $\zeta$ AND ITS ROLE IN CANCER BIOLOGY}

As first described in 1999, increased expression of PKC $\zeta$ is a characteristic of human prostate cancer (28). A subsequent study found that the induction of RNA interference against this kinase in PC3 prostate cancer cells reduced their malignant potential (29), confirming the critical role of $\mathrm{PKC} \zeta$ in promoting the malignant prostatic phenotype. Activation of the atypical kinase is not only necessary but also sufficient to deregulate growth control in mouse fibroblasts. Using a dominant kinase-defective mutant of $\mathrm{PKC} \zeta$, the authors confirmed that the kinase is required for mitogenic activation in fibroblasts (30). Two studies have shown that $\mathrm{PKC} \zeta$ can promote the mobility of human MDA-MB-468 breast cancer cells and pancreatic cancer cells $(31,32)$. However, in these studies, the direct involvement of the $\zeta$ isoform in cancer progression was not well described because the authors only used PS peptide inhibitors and dominant negative mutants of atypical PKC.

Recently, an elegant study performed by Kim et al. showed how PKC $\zeta$ induces the phosphorylation of c-Myc and the consequent inhibition of prostate tumorigenesis. Genetic inactivation of PKC $\zeta$ in mice was reported to result in invasive prostate carcinomas in vivo, which was associated with increased cell growth, invasion, and metastasis; these findings revealed that the phosphorylation of c-Myc on Ser-373 by PKC $\zeta$ is necessary and sufficient to repress c-Myc-activity (33). In 2013, a mechanism by which $\mathrm{PKC} \zeta$ regulates tumor metabolism was described. Here, a lack of $\mathrm{PKC} \zeta$ was found to be essential for reprograming the metabolism of tumor cells deprived of glucose through the utilization of glutamine. This work highlighted the major involvement of the serine biosynthetic cascade controlled by 3-phosphoglycerate dehydrogenase (PHGDH), which was recently shown to be significantly relevant in cancer (34). A recent study showed that overexpression of PKC $\zeta$ inhibits human breast cancer (35), whereas the loss of this kinase promotes growth and colon tumor formation. To verify the hypothesis that $\mathrm{PKC} \zeta$ can promote transformed growth and colon tumor formation, a dominant negative, kinase-deficient $\mathrm{PKC} \zeta$ was overexpressed in $\mathrm{CaCo}_{2}$ human colon cancer cells, which stimulated soft agar growth (36). Moreover, the amount of PKCS is significantly reduced in azoxymethane (AOM)-induced colon tumors in rats, and overexpression of $\mathrm{PKC} \zeta$ inhibits the growth of human MDA-MB-468 breast cancer cells (35).

Based on these reports, it is clear that PKC $\zeta$ influences tumorigenesis through different molecular pathways that sustain proliferative signaling, allow evasion of growth suppressors, reprogram energetic metabolism, and activate invasion and metastasis. Two other pivotal hallmarks of cancer associated with $\mathrm{PKC} \zeta$ have been well examined, i.e., resistance to cell death and inflammation, both of which can be directly linked to the maintenance of the neoplastic phenotype.

We recently demonstrated that $\mathrm{PKC} \zeta$ induces resistance to apoptotic agents following its translocation into the nucleus as a result of oxidative stress (8). Supporting the importance of the role of the nuclear-PKC $\zeta$ fraction in chemoresistance, we have shown that a recombinant nuclear-PKC $\zeta$ inhibitor restores the apoptotic susceptibility of doxorubicin-resistant cells (Figure 1B). Indeed, we have provided direct evidence that doxorubicin-resistant cells present nuclear-PKC $\zeta$ accumulation as a consequence of ROS accumulation (Figure 1B). The involvement of $\mathrm{PKC} \zeta$ through daunorubicin has also been described, where the activation of PKC $\zeta$ triggers the Raf-1/MEK/ERK pathway (37) and inhibits the sphingomyelin-ceramide pathway, favoring daunorubicindependent chemoresistance (38).

This molecular pathway of chemoresistance is counteracted by Rituximab treatments, which inhibit the PKC $/$ MAPK/mTOR pathway in follicular cell lymphoma (39). Treatment of lymphoma cell lines with Rituximab sensitizes the cells to the cytotoxic and apoptotic effects of therapeutic drugs, due partly to modification of the synthesis and secretion of anti-apoptotic cytokines implicated in drug resistance, including IL-6, IL-10, and TNF $\alpha$, and to the inhibition of NF- $\kappa$ B activity $(40,41)$.

The "oncogenic behavior" of ROS has been substantiated by a growing body of evidence $(42,43)$. The ROS within cells act as secondary messengers in intracellular signaling cascades that induce and maintain the oncogenic phenotype of cancer cells, facilitating mutagenesis, tumor promotion, progression, and chemoresistance $(44,45)$. Oxidative stress induces PKC translocation, which is specific for different isoforms and different cell types. For example, in mouse embryonic fibroblasts (MEFs) and HeLa cells, oxidative stress triggers the translocation of the $\mathrm{PKC} \alpha, \beta, \delta$, and $\varepsilon$ isoforms from the cytosol to the plasma membrane (11). Under the same conditions, PKC $\zeta$ translocates to the nucleus in MEFs (46) and HeLa cells (8). We previously described a functional role of nuclear $\mathrm{PKC} \zeta$ in the regulation of cell viability through the suppression of apoptotic cell death, thereby shifting the attention of researchers from cytosolic processes regulated by $\mathrm{PKC} \zeta$, such as sphingomyelinase inactivation (38) or caspase 9 activation (47), to unknown nuclear events. These results support the link between the oncogenic behavior of ROS and the promotion of chemoresistance via nuclear-PKC $\zeta$ translocation. Furthermore, this outcome confirms that nuclear PKC $\zeta$ reduces the sensitivity of cancer cells to chemotherapeutic agents, thus supporting the usefulness of this kinase as a target for tumor cell chemosensitization.

Studies addressing lung cells and MonoMac6 cells exposed to cigarette smoke (a cancer inducer) or lipopolysaccharide (LPS, typically an inflammation inducer) showed that the levels of phosphorylated and total $\mathrm{PKC} \zeta$ increased in the nucleus, where phosphorylated $\mathrm{PKC} \zeta$ formed a complex with the pro-inflammatory transcription factor NF- $\mathrm{B}$ (48).

\section{PKC $\zeta$ AND INFLAMMATION}

Over time, tumor cells can become resistant to anti-neoplastic drugs because molecular escape routes intervene to promote and maintain cancer integrity, thereby avoiding apoptosis or senescence pathways (49-52). A growing body of evidence indicates a role of the inflammatory tumor microenvironment in not only sustaining cancer development but also in cancer responsiveness and resistance to anticancer therapies (53).

Several chemotherapeutic agents can activate the transcription factor NF- $\kappa \mathrm{B}$, thereby promoting chemoresistance through serine phosphorylation of the inhibitor (IKB kinase, IKK) of $\mathrm{I} \kappa \mathrm{B} \alpha(54,55)$. The functions of NF- $\kappa \mathrm{B}$, including transactivation, nuclear translocation, and DNA binding, are blocked by its cellular inhibitor, the I $\mathrm{B} \alpha$ protein. An essential component of the $\mathrm{NF}-\kappa \mathrm{B}$ pathway is the IKK complex, which phosphorylates I $\mathrm{B} \alpha$ and triggers its degradation, releasing NF- $\mathrm{B}$ from its cytosolic 
state and promoting its translocation into the nucleus (56). PKC $\zeta$ phosphorylates the IKK $\beta$ subunit in vitro, possibly through a direct interaction (Figure 2) (57). In HEK293 cells, PKC $\zeta$ interacts with IKK $\beta$ at each catalytic domain in a TNF $\alpha$ stimulation-dependent manner, thereby activating IKK (57). In the lungs of PKC $\zeta$ deficient mice, TNF $\alpha$-induced IKK activation is repressed (58). Indeed, $\mathrm{PKC} \zeta$ has been identified as a ceramide-activated protein kinase that is critical in stress-induced Jun $\mathrm{N}$-terminal kinase activation and NF- $\kappa \mathrm{B}$ translocation (59). In lung carcinogenesis, through its ability to activate NF- $\kappa \mathrm{B}$-dependent inflammation, PKC $\zeta$ triggers survival pathways (60), and the binding of p62 (also known as sequestosome-1, required for both the formation and autophagic degradation of polyubiquitin-containing bodies) to its targets (61). Indeed, the regulation of NF- $\kappa \mathrm{B}$ by the atypical kinase is relevant to Ras-induced oncogenesis $(24,30)$. These findings indicate that $\mathrm{PKC} \zeta$ is involved in the IKK signaling complex and, thus, in NF- $\kappa \mathrm{B}$ activation.

Activated-NF- $\kappa \mathrm{B}$ promotes cytokine production, including that of the positive growth-regulator IL-6, favoring chemoresistance. The importance of IL-6 signaling in mediating tumorigenesis has been examined in a number of studies, and in in vivo

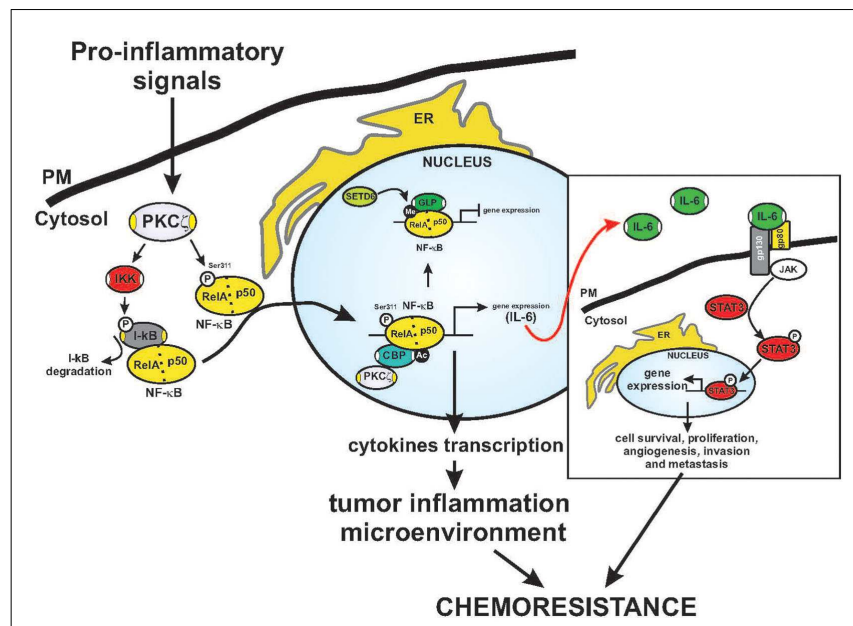

FIGURE 2 | Fine regulation of NF-кB activation by $\mathrm{PKC} \zeta$. Schematic model of the regulation of $\mathrm{PKC} \zeta$ in the inflammatory response and chromatin remodeling. Activated PKC $\zeta$ may activate IKK kinase and trigger $I_{\kappa} B$ degradation. This event precedes NF- $\mathrm{B}$ activation and nuclear translocation, which makes NF-kB free to interact with elements in the promoters of inflammatory and survival genes. Indeed, the $\zeta$ isoform may directly interact with and phosphorylate the RelA subunit on Ser311 (P), leading to increased NF-кB transactivation. The Serine 311 residue is an important residue for recruiting the CBP coactivator complex. This event promotes acetylation $(\mathrm{Ac})$ and the activation of cytokine transcription, that of including IL-6. Under basal conditions, RelA is methylated (Me) by SETD6, promoting the recruitment of GLP, which leads to repression of transcription. STAT3 is a key player in mediating inflammation-driven tumorigenesis, being constitutively activated by chronically high levels of the pro-inflammatory cytokine IL-6. In tumors, STAT3 is known to enhance cell survival and proliferation and to promote immune escape and angiogenesis, invasion, and metastasis. Once activated via tyrosine phosphorylation by receptor-associated JAK kinases, STAT concentrates in the nucleus and regulates the expression of target genes. The established inflammatory tumor microenvironment may contribute to the final outcome of the neoplastic process. studies, IL-6 signaling promotes the growth of tumors (62). Within the tumor microenvironment, IL-6 binds to gp80/gp130, leading to Janus kinase (JAK) activation and phosphorylation of Stat3, which regulates the expression of genes that mediate cellular proliferation and prevent apoptosis (Figure 2) (63). PKC $\zeta$ can control the production of IL-6. Loss of the kinase in vivo leads to increased tumorigenicity linked to the overproduction of IL-6 (26), which is sustained by an inflammatory condition characterized by an M1type immunological response $(64,65)$. IL-6 is a known positive regulator of growth in human tumors, including liver and lung tumors (66); however, its production requires NF- $\mathrm{KB}$ and $\mathrm{PKC} \zeta$ $(58,67)$. IL-1 is known to induce the production of inflammatory cytokines, such as IL-6, through a transcriptional mechanism dependent on NF- $\kappa$ B activation $(68,69)$. Finally, PKC $\zeta$ may regulate IL- 6 promoter activity and transcription through C/EBP $\beta$ regulation via an NF- $\kappa \mathrm{B}$-independent mechanism (26). This finding suggests that PKC $\zeta$ can both positively regulate NF- $\mathrm{B}$ and, at the same time, regulate IL- 6 transcription through independent pathways.

One pathway through which NF- $\kappa \mathrm{B}$ can be activated is the Toll-like receptor (TLR) pathway, which occurs through the adapter protein myeloid differentiation primary response gene 88 (MyD88). NF- $\mathrm{KB}$ activation is a result of underlying inflammation or a consequence of the formation of an inflammatory microenvironment during malignant progression characterized by up-regulation of the tumor promoting cytokines IL-6 and TNF- $\alpha$ (70). Activation of the TNF receptor promotes NF- $\mathrm{B}$ activation in breast cancer cells, leading to increased cancer cell survival and resistance to ionizing radiation (71). Elevated levels of activated-NF- $\kappa \mathrm{B}$ induce cyclin D gene transcription and cell cycle progression, activation of anti-apoptotic genes $b c l-2$ and $b c l-x_{L}$, expression of vascular endothelial growth factor and consequent tumor angiogenesis, activation of transcription factor c-myc, metalloproteinase gene expression, and remodeling of the extra-cellular matrix (72-74).

Cancer-associated p53 mutants acquire significant proinflammatory activity mediated by NF- $\mathrm{B}$, which promotes both tumor initiation and tumor progression (75). Mutant p53 isoforms exhibit a distinct gain-of-function activity, enforcing a chronic state of TNF- $\alpha$-induced NF- $\kappa \mathrm{B}$ activation and resulting in persistent tissue damage, increased genomic instability, extended inflammation, and an augmented capacity for mutant p53-containing cells to evade apoptosis.

Altogether, these data confirm the involvement of the inflammatory tumor microenvironment in cancer, thus, attesting to the contribution of NF- $\mathrm{BB}$ activation in chemoresistance.

Recently, Levy and co-workers described a precise mechanism through which NF- $\mathrm{B}$ activation is controlled directly by Rel A (a subunit of NF- $\kappa$ B) via the methyltransferase SETD6mediated methylation of Lys310 (76). The methylated form of RelA recruits the G9a-related methyltransferase GLP and induces histone methylation, which represses the chromatin state of NF- $\kappa \mathrm{B}$-dependent genes, ensuring that they are not transcribed (Figure 2) (76). This event is coordinated by the PKC- $\zeta$-dependent phosphorylation of Rel A on Ser31, leading to the release of GLP and the recruitment of CBP to RelA, followed by the acetylation of Lys310 and histones, resulting in enhanced transcription 
(Figure 2) (67). This mechanism for the RelA control of NF-кB in inflammation has been observed in PKC $\zeta$-null cells, which are incapable of mounting an efficient inflammatory response to TNF and IL-1. The phenotype of the immune system of PKC $\zeta$-null mice further supports the role of $\mathrm{PKC} \zeta$ in controlling $\mathrm{NF}-\kappa \mathrm{B}$ in vivo (58). These mice display alterations in the development of secondary lymphoid organs, showing morphological defects in the spleen and a reduction in the number of mature B cells (77). Furthermore, they exhibit defects in T helper 2 differentiation, IL-4 production, the nuclear translocation of Stat6 and Rel A (78) and liver damage, which was due to the depletion of protective signals in this organ (79).

\section{CONCLUSION}

The links between inflammation and cancer have been the subject of recent studies, as the identification of the underlying molecular mechanisms may be highly relevant for cancer therapy. The first link between inflammation and cancer was suggested based on the use of anti-inflammatory therapies that have shown efficacy in cancer prevention and treatment (80).

The data described herein indicate that PKC $\zeta$ is critical in the generation of inflammatory cytokines that might decide the final outcome of the neoplastic process. PKC $\zeta$ exhibits both proinflammatory and anti-inflammatory effects, which complicates the interpretation of the findings published thus far. However, data from a study examining the mouse $\mathrm{PKC} \zeta-\mathrm{KO}$ phenotype confirmed the critical contribution of this kinase to inflammation and cancer induction. $\mathrm{PKC} \zeta$ could be considered a tumor suppressor, though other studies have elucidated functional contributions of the connection of $\mathrm{PKC} \zeta$ to NF- $\kappa \mathrm{B}$ and Stat $3 / \mathrm{IL}-6$ in carcinogenesis.

\section{REFERENCES}

1. Bononi A, Agnoletto C, De Marchi E, Marchi S, Patergnani S, Bonora $\mathrm{M}$, et al. Protein kinases and phosphatases in the control of cell fate. Enzyme Res (2011) 2011:329098. doi:10.4061/2011/329098

2. Giorgi C, Agnoletto C, Baldini C, Bononi A, Bonora M, Marchi $\mathrm{S}$, et al. Redox control of protein kinase C: cell- and diseasespecific aspects. Antioxid Redox Signal (2010) 13(7):1051-85. doi: 10.1089/ars.2009.2825

3. Rosse C, Linch M, Kermorgant S, Cameron AJ, Boeckeler K, Parker PJ. PKC and the control of localized signal dynamics. Nat Rev (2010) 11(2):103-12. doi:10.1038/ nrm2847

4. Ono Y, Fujii T, Ogita K, Kikkawa U, Igarashi K, Nishizuka Y. Protein kinase $\mathrm{C}$ zeta subspecies from rat brain: its structure, expression, and properties. Proc Natl Acad Sci U S A (1989) 86(9):3099-103. doi:10. 1073/pnas.86.9.3099

5. Nakanishi H, Brewer KA, Exton JH. Activation of the zeta isozyme of protein kinase $\mathrm{C}$

The molecular mechanism by which $\mathrm{PKC} \zeta$ participates in multilevel regulation is strictly dependent on cell type and intracellular localization.

The data obtained from $\mathrm{PKC} \zeta$-null mice describe the real biological contribution of the kinase, at least in part. Genetic ablation of PKC $\zeta$ leads to a global, dramatic shutdown of the regulation of the master regulator proteins associated with inflammation, cancer, and apoptosis. Here, a limiting factor is that the available data do not permit the discrimination of individual molecular mechanisms in which PKC $\zeta$ is involved.

An emerging concept is that the different functionalities of $\mathrm{PKC} \zeta$ are related to its intracellular distribution. The nucleus appears to be a functional site for $\mathrm{PKC} \zeta$; this localization is regulated by oxidative stress, which is a condition present during both chemoresistance and inflammation. Nuclear-PKC $\zeta$ redistribution reduces the sensitivity of cancer cells to chemotherapeutic agents, tagging this kinase as a useful target for tumor cell chemosensitization. Understanding the real molecular roles of nuclear PKC $\zeta$ will be the next step in defining the specific mechanism that links oxidative stress, inflammation, and chemoresistance.

\section{ACKNOWLEDGMENTS}

This study was supported by: the Italian Ministry of Health to Alessandro Rimessi; the Italian Association for Cancer Research (AIRC); Telethon (GGP11139B); local funds from the University of Ferrara; the Italian Ministry of Education, University and Research (COFIN, FIRB, and Futuro in Ricerca); and the Italian Ministry of Health to Paolo Pinton. Simone Patergnani was supported by a FISM (Fondazione Italiana Sclerosi Multipla) research fellowship (2012/B/11).

muscle in response to fasting and refeeding. $\mathrm{Br} \quad \mathrm{N}$ Nutr (1999) 81(2):153-7.

10. Hirai T, Chida K. Protein kinase Czeta (PKCzeta): activation mechanisms and cellular functions. $J$ Biochem (2003) 133(1):1-7. doi: $10.1093 / \mathrm{jb} / \mathrm{mvg} 017$

11. Rimessi A, Rizzuto R, Pinton P. Differential recruitment of $\mathrm{PKC}$ isoforms in HeLa cells during redox stress. Cell Stress Chaperones (2007) 12(4):291-8. doi:10.1379/ CSC-211.1

12. Cross CE, Halliwell B, Borish ET, Pryor WA, Ames BN, Saul RL, et al. Oxygen radicals and human disease. Ann Intern Med (1987) 107(4):526-45. doi:10.7326/00034819-107-4-526

13. Cui X. Reactive oxygen species: the achilles' heel of cancer cells? Antioxid Redox Signal (2012) 16(11):1212-4. doi:10.1089/ars.2012.4532

14. Lee DJ, Kang SW. Reactive oxygen species and tumor metastasis. Mol Cells (2013) 35(2): 93-8. doi:10.1007/s10059-0130034-9
15. Marchi S, Giorgi C, Suski JM Agnoletto C, Bononi A, Bonora M, et al. Mitochondria-ros crosstalk in the control of cell death and aging. J Signal Transduct (2012) 2012:329635. doi:10.1155/ 2012/329635

16. O'Brian CA, Ward NE. Biology of the protein kinase C family. Cancer Metastasis Rev (1989) 8(3):199-214. doi:10.1007/ BF00047337

17. Urtreger AJ, Kazanietz MG. Bal de Kier Joffe ED. Contribution of individual PKC isoforms to breast cancer progression. IUBMB Life (2012) 64(1):18-26. doi:10.1002/ iub. 574

18. Ponting CP, Ito T, Moscat J, Diaz-Meco MT, Inagaki F, Sumimoto H. OPR PC and AID: all in the PB1 family. Trends Biochem Sci (2002) 27(1):10. doi:10.1016/S0968-0004(01) 02006-0

19. Nigg EA. Nucleocytoplasmic transport: signals, mechanisms and regulation. Nature (1997) 386(6627):779-87. doi: $10.1038 / 386779 \mathrm{a} 0$ 
20. Ossareh-Nazari B, Bachelerie F, Dargemont C. Evidence for a role of CRM1 in signalmediated nuclear protein export. Science (1997) 278(5335): 141-4. doi:10.1126/science.278 5335.141

21. Murray NR, Jamieson L, Yu W, Zhang J, Gökmen-Polar Y, Sier D, et al. Protein kinase Ciota is required for Ras transformation and colon carcinogenesis in vivo. J Cell Biol (2004) 164(6):797-802. doi:10.1083/jcb.200311011

22. Jin Z, Xin M, Deng X. Survival function of protein kinase $\mathrm{C}\{$ iota $\}$ as a novel nitrosamine 4-(methylnitrosamino)-1-(3pyridyl)-1-butanone-activated bad kinase. $J$ Biol Chem (2005) 280(16):16045-52. doi:10.1074/jbc.M413488200

23. Fields AP, Regala RP. Protein kinase C iota: human oncogene, prognostic marker and therapeutic target. Pharmacol Res (2007) 55(6):487-97. doi:10.1016/j.phrs. 2007.04.015

24. Diaz-Meco MT, Lozano J, Municio MM, Berra E, Frutos S, Sanz $\mathrm{L}$, et al. Evidence for the in vitro and in vivo interaction of Ras with protein kinase $\mathrm{C}$ zeta. J Biol Chem (1994) 269(50):31706-10.

25. Wood LD, Parsons DW, Jones S, Lin J, Sjöblom T, Leary RJ, et al. The genomic landscapes of human breast and colorectal cancers. Science (2007) 318(5853):1108-13. doi:10.1126/science. 1145720

26. Galvez AS, Duran A, Linares JF, Pathrose P, Castilla EA, Abu-Baker $S$, et al. Protein kinase Czeta represses the interleukin-6 promoter and impairs tumorigenesis in vivo. Mol Cell Biol (2009) 29(1):104-15. doi:10.1128/MCB. 01294-08

27. Luna-Ulloa LB, HernandezMaqueda JG, Santoyo-Ramos P, Castaneda-Patlan MC, RoblesFlores M. Protein kinase C zeta is a positive modulator of canonical Wnt signaling pathway in tumoral colon cell lines. Carcinogenesis (2011) 32(11):1615-24. doi:10.1093/carcin/bgr190

28. Cornford P, Evans J, Dodson A, Parsons K, Woolfenden A, Neoptolemos J, et al. Protein kinase C isoenzyme patterns characteristically modulated in early prostate cancer. Am J Pathol (1999) 154(1):137-44. doi:10. 1016/S0002-9440(10)65260- 1

29. Yao S, Bee A, Brewer D, Dodson A, Beesley C, Ke Y, et al. PRKC-zeta expression promotes the aggressive phenotype of human prostate cancer cells and is a novel target for therapeutic intervention. Genes Cancer (2010) 1(5):444-64. doi: 10.1177/1947601910376079

30. Berra E, Diaz-Meco MT, Dominguez I, Municio MM, Sanz L, Lozano J, et al. Protein kinase C zeta isoform is critical for mitogenic signal transduction. Cell (1993) 74(3):555-63. doi:10. 1016/0092-8674(93)80056-K

31. Laudanna C, Sorio C, Tecchio C, Butcher EC, Bonora A, Bassi C, et al. Motility analysis of pancreatic adenocarcinoma cells reveals a role for the atypical zeta isoform of protein kinase $\mathrm{C}$ in cancer cell movement. Lab Invest (2003) 83(8):1155-63. doi:10.1097/01. LAB.0000081390.92179.F3

32. Sun R, Gao P, Chen L, Ma D, Wang J, Oppenheim JJ, et al. Protein kinase $\mathrm{C}$ zeta is required for epidermal growth factor-induced chemotaxis of human breast cancer cells. Cancer Res (2005) 65(4):1433-41. doi:10.1158/00085472.CAN-04- 1163

33. Kim JY, Valencia T, Abu-Baker $S$, Linares J, Lee SJ, Yajima T, et al. cMyc phosphorylation by PKCzeta represses prostate tumorigenesis. Proc Natl Acad Sci U S A (2013) 110(16):6418-23. doi:10. 1073/pnas.1221799110

34. Ma L, Tao Y, Duran A, Llado V, Galvez A, Barger JF, et al. Control of nutrient stress-induced metabolic reprogramming by PKCzeta in tumorigenesis. Cell (2013) 152(3):599-611. doi:10.1016/j.cell.2012.12.028

35. Mao M, Fang X, Lu Y, Lapushin $\mathrm{R}$, Bast RC Jr, Mills GB. Inhibition of growth-factor-induced phosphorylation and activation of protein kinase $\mathrm{B} / \mathrm{Akt}$ by atypical protein kinase $\mathrm{C}$ in breast cancer cells. Biochem J (2000) 352(Pt 2):475-82. doi:10.1042/ 0264-6021:3520475

36. Mustafi R, Cerda S, Chumsangsri A, Fichera A, Bissonnette M. Protein kinase-zeta inhibits collagen I-dependent and anchorageindependent growth and enhances apoptosis of human Caco-2 cells. Mol Cancer Res (2006) 4(9):683-94. doi:10.1158/15417786.MCR-06-0057

37. Mas VM, Hernandez H, Plo I, Bezombes C, Maestre N, Quillet-Mary A, et al. Protein kinase Czeta mediated Raf1/extracellular-regulated kinase activation by daunorubicin. Blood (2003) 101(4):1543-50. doi:10.1182/blood-2002-05-1585

38. Bezombes C, de Thonel A, Apostolou A, Louat T, Jaffrézou JP, Laurent $\mathrm{G}$, et al. Overexpression of protein kinase Czeta confers protection against antileukemic drugs by inhibiting the redox-dependent sphingomyelinase activation. $\mathrm{Mol}$ Pharmacol (2002) 62(6):1446-55. doi:10.1124/mol.62.6.1446

39. Leseux L, Laurent G, Laurent C, Rigo M, Blanc A, Olive D et al. PKC zeta mTOR pathway: a new target for rituximab therapy in follicular lymphoma. Blood (2008) 111(1):285-91. doi: 10.1182/blood-2007-04-085092

40. Alas S, Emmanouilides C, Bonavida B. Inhibition of interleukin 10 by rituximab results in down-regulation of bcl-2 and sensitization of B-cell non-Hodgkin's lymphoma to apoptosis. Clin Cancer Res (2001) 7(3):709-23.

41. Vega MI, Jazirehi AR, HuertaYepez S, Bonavida B. Rituximabinduced inhibition of YY1 and Bcl-xL expression in Ramos nonHodgkin's lymphoma cell line via inhibition of NF-kappa B activity: role of YY1 and Bcl-xL in Fas resistance and chemoresistance, respectively. J Immunol (2005) 175(4):2174-83.

42. Fang J, Seki T, Maeda H. Therapeutic strategies by modulating oxygen stress in cancer and inflammation. Adv Drug Deliv Rev (2009) 61(4):290-302. doi:10.1016/j.addr. 2009.02.005

43. Khandrika L, Kumar B, Koul S, Maroni P, Koul HK. Oxidative stress in prostate cancer. Cancer Lett (2009) 282(2):125-36. doi:10. 1016/j.canlet.2008.12.011

44. Reuter S, Gupta SC, Chaturvedi MM, Aggarwal BB. Oxidative stress, inflammation, and cancer: how are they linked? Free Radic Biol Med (2010) 49(11):1603-16. doi:10.1016/j.freeradbiomed. 2010.09.006

45. Visconti R, Grieco D. New insights on oxidative stress in cancer. Cur Opin Drug Discov Devel (2009) 12(2):240-5.

46. Pinton P, Rimessi A, Marchi S, Orsini F, Migliaccio E, Giorgio $\mathrm{M}$, et al. Protein kinase $\mathrm{C}$ beta and prolyl isomerase 1 regulate mitochondrial effects of the lifespan determinant p66Shc. Science (2007) 315(5812):659-63. doi:10. $1126 /$ science. 1135380

47. Brady SC, Allan LA, Clarke PR. Regulation of caspase 9 through phosphorylation by protein kinase $\mathrm{C}$ zeta in response to hyperosmotic stress. Mol Cell Biol (2005) 25(23):10543-55. doi:10.1128/MCB.25.23.1054310555.2005

48. Yao H, Hwang JW, Moscat J, DiazMeco MT, Leitges M, Kishore N, et al. Protein kinase $\mathrm{C}$ zeta mediates cigarette smoke/aldehyde- and lipopolysaccharide-induced lung inflammation and histone modifications. J Biol Chem (2010) 285(8):5405-16. doi:10.1074/jbc. M109.041418

49. Borst P, Jonkers J, Rottenberg S. What makes tumors multidrug resistant? Cell Cycle (2007) 6(22):2782-7. doi:10.4161/cc.6.22. 4936

50. Schmitt CA, Fridman JS, Yang M, Lee S, Baranov E, Hoffman $\mathrm{RM}$, et al. A senescence program controlled by p53 and p16INK4a contributes to the outcome of cancer therapy. Cell (2002) 109(3):335-46. doi:10.1016/ S0092-8674(02)00734- 1

51. Szakacs G, Paterson JK, Ludwig JA, Booth-Genthe C, Gottesman MM. Targeting multidrug resistance in cancer. Nat Rev Drug Discov (2006) 5(3):219-34. doi:10.1038/ $\operatorname{nrd} 1984$

52. Voorzanger-Rousselot N, Alberti L, Blay JY. CD40L induces multidrug resistance to apoptosis in breast carcinoma and lymphoma cells through caspase independent and dependent pathways. BMC Cancer (2006) 6:75. doi:10.1186/14712407-6-75

53. de Visser KE, Jonkers J. Towards understanding the role of cancerassociated inflammation in chemoresistance. Curr Pharm Des (2009) 15(16):1844-53 doi:10.2174/138161209788453239

54. Ahn KS, Sethi G, Aggarwal BB. Nuclear factor-kappa B: from clone to clinic. Curr $\mathrm{Mol} \mathrm{Med}$ (2007) 7(7):619-37. doi:10.2174/ 156652407782564363

55. Raju U, Gumin GJ, Noel F, Tofilon PJ. IkappaBalpha degradation is not a requirement for the $\mathrm{X}$ ray-induced activation of nuclear factor kappaB in normal rat astrocytes and human brain tumour cells. Int $I$ Radiat Biol (1998) 74(5):617-24. doi:10.1080/095530098141195

56. Karin M. The beginning of the end: IkappaB kinase (IKK) and NF-kappaB activation. J Biol Chem (1999) 274(39):27339-42. doi:10. 1074/jbc.274.39.27339

57. Lallena MJ, Diaz-Meco MT, Bren G, Paya CV, Moscat J. Activation of IkappaB kinase beta by protein 
kinase C isoforms. Mol Cell Biol (1999) 19(3):2180-8.

58. Leitges M, Sanz L, Martin P, Duran A, Braun U, García JF, et al. Targeted disruption of the zetaPKC gene results in the impairment of the NF-kappaB pathway. Mol Cell (2001) 8(4):771-80. doi:10.1016/ S1097-2765(01)00361-6

59. Bourbon NA, Yun J, Kester M. Ceramide directly activates protein kinase $\mathrm{C}$ zeta to regulate a stress-activated protein kinase signaling complex. $\mathrm{J}$ Biol Chem (2000) 275(45):35617-23. doi:10 . 1074/jbc.M007346200

60. Duran A, Linares JF, Galvez AS, Wikenheiser K, Flores JM, Diaz-Meco MT, et al. The signaling adaptor p62 is an important NF-kappaB mediator in tumorigenesis. Cancer Cell (2008) 13(4):343-54. doi:10.1016/j.ccr.2008.02.001

61. Moscat J, Diaz-Meco MT, Albert A, Campuzano S. Cell signaling and function organized by PB1 domain interactions. Mol Cell (2006) 23(5):631-40. doi:10.1016/ j.molcel.2006.08.002

62. Knupfer H, Preiss R. Significance of interleukin-6 (IL-6) in breast cancer (review). Breast Cancer Res Treat (2007) 102(2):129-35. doi: 10.1007/s10549-006-9328-3

63. Bromberg J, Wang TC. Inflammation and cancer: IL-6 and STAT3 complete the link. Cancer Cell (2009) 15(2):79-80. doi:10.1016/j. ccr.2009.01.009

64. Balkwill F, Charles KA, Mantovani A. Smoldering and polarized inflammation in the initiation and promotion of malignant disease. Cancer Cell (2005) 7(3):211-7. doi: 10.1016/j.ccr.2005.02.013

65. Pollard JW. Tumour-educated macrophages promote tumour progression and metastasis. Nat Rev Cancer (2004) 4(1):71-8. doi:10.1038/nrc1256

66. Grivennikov S, Karin M. Autocrine IL-6 signaling: a key event in tumorigenesis? Cancer Cell (2008) 13(1):7-9. doi:10.1016/j.ccr.2007. 12.020

67. Duran A, Diaz-Meco MT, Moscat J. Essential role of RelA Ser311 phosphorylation by zetaPKC in NFkappaB transcriptional activation. EMBO J (2003) 22(15):3910-8. doi:10.1093/emboj/cdg370

68. Goto M, Katayama KI, Shirakawa $\mathrm{F}$, Tanaka I. Involvement of NF-kappaB p50/p65 heterodimer in activation of the human pro-interleukin-1beta gene at two subregions of the upstream enhancer element. Cytokine (1999) 11(1):16-28. doi:10.1006/cyto.1998.0390

69. Thomas JA, Allen JL, Tsen M, Dubnicoff T, Danao J, Liao XC, et al. Impaired cytokine signaling in mice lacking the IL1 receptor-associated kinase. $J$ Immunol (1999) 163(2):978-84.

70. Karin M. NF-kappaB as a critical link between inflammation and cancer. Cold Spring Harb Perspect Biol (2009) 1(5):a000141. doi:10. 1101/cshperspect.a000141

71. Braunstein S, Formenti SC, Schneider RJ. Acquisition of stable inducible up-regulation of nuclear factor-kappaB by tumor necrosis factor exposure confers increased radiation resistance without increased transformation in breast cancer cells. Mol Cancer Res (2008) 6(1):78-88. doi:10. 1158/1541-7786.MCR-07-0339

72. Takebayashi T, Higashi H, Sudo H, Ozawa H, Suzuki E, Shirado O, et al. NF-kappa B-dependent induction of cyclin D1 by retinoblastoma protein (pRB) family proteins and tumor-derived pRB mutants. J Biol Chem (2003) 278(17):14897-905. doi:10.1074/jbc.M210849200

73. Pham LV, Tamayo AT, Yoshimura LC, Lo P, Ford RJ. Inhibition of constitutive NF-kappa B activation in mantle cell lymphoma B cells leads to induction of cell cycle arrest and apoptosis. J Immunol (2003) 171(1):88-95.

74. Cuní S, Pérez-Aciego P, PérezChacón G, Vargas JA, Sánchez A, Martín-Saavedra FM, et al. A sustained activation of PI3K/NFkappaB pathway is critical for the survival of chronic lymphocytic leukemia B cells. Leukemia (2004) 18(8):1391-400. doi:10. 1038/sj.leu.2403398

75. Cooks T, Pateras IS, Tarcic $\mathrm{O}$, Solomon $\mathrm{H}$, Schetter AJ, Wilder S, et al. Mutant p53 prolongs NF-kappaB activation and promotes chronic inflammation and inflammationassociated colorectal cancer Cancer Cell (2013) 23(5):634-46. doi:10.1016/j.ccr.2013.03.022

76. Levy D, Kuo AJ, Chang Y, Schaefer U, Kitson C, Cheung P, et al. Lysine methylation of the NFkappaB subunit RelA by SETD6 couples activity of the histone methyltransferase GLP at chromatin to tonic repression of NFkappaB signaling. Nat Immunol (2011) 12(1):29-36. doi:10.1038/ ni. 1968

77. Martin P, Duran A, Minguet S, Gaspar ML, Diaz-Meco MT, Rennert $\mathrm{P}$, et al. Role of zeta PKC in B-cell signaling and function. EMBO J (2002) 21(15):4049-57. doi:10.1093/emboj/cdf407

78. Martin P, Villares R, RodriguezMascarenhas S, Zaballos A, Leitges $\mathrm{M}$, Kovac J, et al. Control of $\mathrm{T}$ helper 2 cell function and allergic airway inflammation by PKCzeta. Proc Natl Acad Sci U S A (2005) 102(28):9866-71. doi:10. 1073/pnas.0501202102

79. Ghosh S, Karin M. Missing pieces in the NF-kappaB puzzle. Cell (2002) 109(Suppl):S81-96. doi:10. 1016/S0092-8674(02)00703-1

80. Gonda TA, Tu S, Wang TC. Chronic inflammation, the tumor microenvironment and carcinogenesis. Cell Cycle (2009) 8(13):2005-13. doi: $10.4161 /$ cc.8.13.8985

Conflict of Interest Statement: The authors declare that the research was conducted in the absence of any commercial or financial relationships that could be construed as a potential conflict of interest.

Received: 10 June 2013; paper pending published: 08 July 2013; accepted: 24 August 2013; published online: $12 \mathrm{Sep}$ tember 2013.

Citation: Rimessi A, Patergnani S, Ioannidi $E$ and Pinton P (2013) Chemoresistance and cancer-related inflammation: two hallmarks of cancer connected by an atypical link, PKCל. Front. Oncol. 3:232. doi: 10.3389/fonc.2013.00232

This article was submitted to Molecular and Cellular Oncology, a section of the journal Frontiers in Oncology.

Copyright (๑) 2013 Rimessi, Patergnani, Ioannidi and Pinton. This is an openaccess article distributed under the terms of the Creative Commons Attribution License (CC BY). The use, distribution or reproduction in other forums is permitted, provided the original author(s) or licensor are credited and that the original publication in this journal is cited, in accordance with accepted academic practice. No use, distribution or reproduction is permitted which does not comply with these terms. 